\title{
Apple, grape or orange juice: Which one offers the best substrate for lactobacilli growth? - A screening study on bacteria viability, superoxide dismutase activity, folates production and hedonic characteristics
}

\author{
Ana Paula Espirito-Santo *, Frédéric Carlin, Catherine M.G.C. Renard \\ a INRA, UMR408 Sécurité et Qualité des Produits d'Origine Végétale, F-84000 Avignon, France \\ b Université d'Avignon et des Pays de Vaucluse, UMR408 Sécurité et Qualité des Produits d'Origine Végétale, F-84000 Avignon, France
}

Keywords:

Lactobacillus

Fruit juice fermentation

Folate

Antioxidant enzyme

Acceptability test

Chemical compounds studied in this article:

Acetonitrile (PubChem CID: 6342)

p-Aminobenzoic acid (PubChem CID: 978)

Formic acid (PubChem CID: 284)

2-(4-Iodophenyl)-3-(4-nitrophenyl)-5-

(2,4-disulphophenyl)-2 $\mathrm{H}$-tetrazolium,

monosodium salt (PubChem CID: 11,399,451)

5-Methyltetrahydrofolic acid diglutamate

(PubChem CID: 40,114)

5-Methyltetrahydrofolic acid monoglutamate

(PubChem CID: 42,626,431)

Sodium chloride (PubChem CID: 5234)

\begin{abstract}
A B S T R A C T
Fermentation can contribute to improve functional aspects of foods. The first goal of this study was to determine amongst apple, grape and orange juices, the one with the best bacterial growth performance during fermentation by Lactobacillus strains from commercial and artisanal food origins, at $40{ }^{\circ} \mathrm{C}$ for $48 \mathrm{~h}$. The juice with the highest bacterial growth was evaluated for bacteria viability during 4 weeks of cold storage, superoxide dismutase (SOD) activity and folates production analyzed through HPLC/fluorimetry. Acceptability of fermented juice was appraised through hedonic analysis. Lactobacilli counts were the highest in apple and the lowest in orange juices at $\mathrm{t}=48 \mathrm{~h}$. In most cases, bacteria counts were higher in fermented ( 5.5 to $9.5 \log \mathrm{CFU} / \mathrm{ml}$ ) than in supplemented apple juices ( 4.2 to $5.7 \log \mathrm{CFU} / \mathrm{ml}$ ), at the 4 th week of cold storage. SOD activity was significantly increased in all apple juices fermented by commercial Lactobacilli strains. Folates were produced in apple juices fermented by Lactobacillus plantarum and Lactobacillus rhamnosus. Apple juice was the best substrate for Lactobacillus growth and, considering bacterial viability and overall acceptance by the panelists, Lactobacillus acidophilus L10 was the most suitable strain for apple juice fermentation.
\end{abstract}

\section{Introduction}

An important portion of the market of functional foods is represented by foods containing probiotics (Siegrist, Stampfli, \& Kastenholz, 2008), which have been defined as live microorganisms that, when consumed in adequate amounts, confer health benefit on the host (FAO/WHO, 2006). This concept has been systematically debated by the European Food Safety Authority (EFSA), which remarks the lack of irrefutable scientific proof of 'beneficial physiological effect' of many probiotic claims (Katan, 2012). However, the market of probiotic food continues to grow

\footnotetext{
* Corresponding author at: Institut National de Recherche Agronomique, INRA-PACA UMR408 "Sécurité et Qualité des Produits d'Origine Végétale", France.

E-mail addresses: ana-paula.do-espirito-santo@paca.inra.fr, paulaes17@hotmail.com (A.P. Espirito-Santo).
}

at rates of 7\%/year worldwide (Foligné, Daniel, \& Pot, 2013). Dairy matrices, markedly yoghurt, have been systematically studied and commercialized as vehicles for probiotics intake (Granato, Branco, \& Nazzaro, 2010). However, in addition to the needs of vegan diet consumers, the high prevalence of lactose intolerance in worldwide population is boosting the diversification of the delivery vehicles available, beyond the traditional use of dairy systems (Espirito Santo, Perego, Converti, \& Oliveira, 2011). In this sense, fruit juices are perceived as healthy food product by consumers and have been suggested as an appropriate medium for supplementation with probiotic bacteria, being the species of Lactobacilli the most used for probiotication (Espirito Santo et al., 2011; Martins et al., 2013). Nevertheless, the development of non-dairy products containing probiotic is a challenge, as their viability is highly dependent on factors inherent to the food matrix and to food process such as base nutrients, $\mathrm{pH}$, presence of inhibitor substances, oxygen level and 
temperature of storage (Champagne, Raymond, \& Gagnon, 2008; Mattila-Sandholm, Myllärinen, Crittenden, Mogensen, \& Fondén, 2002). In this context, the choice of the probiotic bacteria strain, the best adapted to a given substrate, is of outmost importance (Ranadheera, Baines, \& Adams, 2010).

Apart from supplementation, the fermentation of a food matrix by probiotic cultures consists in another way of probiotication which can contribute to further technological and/or health benefits (Rakin, Vukasinovic, Siler-Marinkovic, \& Maksimovic, 2007; Stanton, Ross, Fitzgerald, \& Van Sinderen, 2005). Beyond the probiotic claim itself, metabolites produced during fermentation by probiotic bacteria can be responsible for the improvement of functional aspects of the foods (biogenic effect), amongst which one can mention the production of B-group vitamins such as folates (Jägerstad, Jastrebova, \& Svensson, 2004; LeBlanc et al., 2013), functional fatty acids (Espírito-Santo et al., 2012) and anti-hypertensive peptides (Agyei \& Danquah, 2012; Ankolekar, Pinto, Greene, \& Shetty, 2012). As a response to oxidative stress during fermentation, species of lactobacilli and bifidobacteria can produce anti-oxidant substances such as NADH, NADPH, glutathione and superoxide dismutase (SOD) enzyme. These substances are able to decrease the risk of accumulation of reactive oxygen species (ROS), thus increasing the bacteria cell viability and the antioxidant capacity of the food (Lin \& Yen, 1999; Wang, Yu, \& Chou, 2006). The reduction of undesirable substances such as nondigestible oligosaccharides (Hou, Yu, \& Chou, 2000) is also an advantage of fermentation.

Herein, apple, grape and orange juices were considered as substrate for fermentation by monocultures of Lactobacillus species, which are present in commercial and artisanal food products and have large scientific documentation of safety and health benefits (FAO/WHO, 2006; Galdeano \& Perdigon, 2004; Gobbetti, Di Cagno, \& De Angelis, 2010; Isolauri, Salminen, \& Ouwehand, 2004; Jones, Tomaro-Duchesneau, \& Prakash, 2014; Peran et al., 2007). The first goal was to determine and select the juice with the best bacterial growth performance during fermentation. Afterwards, considering cell viability during 28 days of cold storage, fermentation process was confronted to the simple supplementation of the chosen fruit juice with free lactobacilli strains. The influence of fermentation on $\mathrm{pH}, \mathrm{SOD}$ activity, production of folates and hedonic characteristics of the selected fruit juice, were also appraised. This screening study is concentrated on the effect of each one of the bacteria strains tested on the food matrix (and vice-versa) during fermentation and is part of a larger project on the impact of fermentation on functional compounds of vegetable food matrices.

\section{Materials and methods}

\subsection{Fruit juices}

Microfiltrated apple juice of 'Golden Delicious' variety, was produced as described in Hubert, Baron, Le Queré, and Renard (2007) and purchased from IFPC (Institut Français des Productions Cidricoles, Le Rheu, France). Orange juice (Joker $\left.{ }^{\circledR}\right)$ without pulp and grape var. 'Muscat' juice (Casino Bio ${ }^{\circledR}$ ), both $100 \%$ fruit juice without pulp and additives or preservatives, were purchased in local supermarkets in Avignon, France. Dry matter contents of apple, grape and orange juices were $12.1( \pm 0.1), 16.6( \pm 0.2)$ and $11.5( \pm 0.2) \mathrm{g} / 100 \mathrm{ml}$, respectively.

\subsection{Bacteria cultures}

In this study we used freeze-dried commercial cultures of Lactobacillus acidophilus Lafti L10, Lactobacillus casei Lafti L26 (DSM, Moorebank, Australia) and Lactobacillus rhamnosus LGG (ATCC 53103), and cultures isolated from commercially available products: Lactobacillus paracasei Lp33 (Christian Hansen, Denmark), Lactobacillus plantarum 299v (Probi $A B$, Sweden). Lactobacilli strains isolated from artisanal food products and maintained in the INRA collection were also used: L. acidophilus (CIRMBIA 1674, CNRZ 204), L. casei (CIRMBIA 667, CNRZ 313),
L. paracasei (CIRMBIA 672, CNRZ 62), L. plantarum (CIRMBIA 466, CNRZ 211) and L. rhamnosus (CIRMBIA 607, CNRZ 212). The identity of Lactobacillus species isolated from commercial products was confirmed through amplification of DNA from the 16S rRNA which were then compared to sequences deposited on BQ GenBank-EMBL by using BLASTN program of National Centre for Biotechnology Information, NCBI (http://www. ncbi.nlm.nih.gov), and identified to a species with \% of homology $>97 \%$.

\subsection{Fermentation procedures and supplementation with lactobacilli strains}

Lactobacilli cultures were previously inoculated into MRS (de Man, Rogosa, and Sharpe) broth (Biokar diagnostics, Beauvais, France) and incubated at $40{ }^{\circ} \mathrm{C}$ for $12 \mathrm{~h}$. Then, the resulting cultures were adapted to the growth conditions of the fruit juices. The final cultures were centrifuged at $5000 \times \mathrm{g}$ for $5 \mathrm{~min}$ and the resulting bacterial pellets were washed three times with a sterile solution of $\mathrm{NaCl} 0.9 \%(\mathrm{w} / \mathrm{v})$ and once with the fruit juice. The resulting pellet was re-suspended in a volume of fruit juice enough to achieve bacteria counts of $10^{9} \mathrm{CFU} / \mathrm{ml}$, verified through culture on MRS agar (Biokar diagnostics, Beauvais, France) in petri dishes and incubation at $37^{\circ} \mathrm{C}$ for $48 \mathrm{~h}$ under anaerobiosis.

Juices were divided into $10 \mathrm{ml}$ aliquots in sterile BD Falcon ${ }^{\circledR}$ tubes of $15 \mathrm{ml}$, inoculated with $1 \%$ of inoculum at $10^{9} \mathrm{CFU} / \mathrm{ml}$ and then incubated in water bath at $40{ }^{\circ} \mathrm{C}$ for $48 \mathrm{~h}$, under agitation of $100 \mathrm{rpm}$. Tubes in triplicate were prepared for 8,24 and $48 \mathrm{~h}$ of fermentation and for 1,14 and 28 days of cold storage at $5{ }^{\circ} \mathrm{C}$, after $48 \mathrm{~h}$ of fermentation. Tubes were retrieved at each established fermentation time and cooled until $20^{\circ} \mathrm{C}$ in ice bath. The contamination by yeasts was controlled through immersion phase-contrast optical microscopy at $\times 1000$ magnification (Olympus BX50, Olympus Optical Co., Ltd., Hamburg, Germany) periodically during fermentation. Independent batch fermentations were repeated twice. Juices without inoculum were maintained under the same fermentation conditions and used as control for all the analysis.

The evolution of $\mathrm{pH}$ during fermentation and during cold storage was controlled for each tube with a pH meter (Mettler Toledo FE20, Schwerzenbach, Switzerland) and pH electrode (Mettler Toledo Electrode LE438) calibrated with freshly prepared buffers ( $\mathrm{pH} 4.00$ and pH 7.01) (Merck, Darmstadt, Germany).

In order to evaluate whether or not the fermentation process contributes to better cell viability during shelf-life, the fruit juice presenting the highest bacteria counts by $48 \mathrm{~h}$ of fermentation was chosen to undergo a simple supplementation with the lactobacilli strains. The nonfermented selected fruit juice at $5{ }^{\circ} \mathrm{C}$ was inoculated with fresh cell suspension of lactobacilli strains at $9 \log \mathrm{CFU} / \mathrm{ml}$ and kept for 4 weeks under cold storage at $5( \pm 1){ }^{\circ} \mathrm{C}$ after inoculation. Three independent replications of supplementation were performed.

\subsection{Lactobacilli enumeration}

Viable Lactobacillus counts were carried out in triplicate at 8, 24 and $48 \mathrm{~h}$ of fermentation and on days 1 and 28 of cold storage of fermented and supplemented juices. Appropriate serial decimal dilutions of samples $(100 \mu \mathrm{l})$ of juices in sterile $0.9 \% \mathrm{NaCl}(900 \mu \mathrm{l})$ were inoculated into MRS agar at $\mathrm{pH} 6.2$, applying the pour plate technique, followed by incubation at $37^{\circ} \mathrm{C}$ for $48 \mathrm{~h}$ under anaerobiosis. Afterwards, isolated colonies were counted and the results were expressed in $\log \mathrm{CFU} / \mathrm{ml}$ of juice.

\subsection{Superoxide dismutase activity assay}

The determination of SOD activity was carried out in triplicate at 0, 4, 8,24 and 48 h of fermentation only for the fruit juice with the best performance in bacteria growth during fermentation and viability in cold storage, i.e. apple juice. The superoxide anion scavenging activity of the fermented juices was determined by the WST (2-(4-iodophenyl)-3-(4nitrophenyl)-5-(2,4-disulphophenyl)-2H-tetrazolium, monosodium salt) reduction method, using the SOD assay kit (Sigma-Aldrich, St. 
Louis, USA). This method is based on the reduction of WST-1 by superoxide radical $\left(\mathrm{O}_{2} \bullet-\right)$ producing yellow formazan, which was measured at $450 \mathrm{~nm}$ in a spectrofluorometer SAFAS FLX-Xenius, Monaco. Antioxidant enzymes such as SOD inhibit the formation of WST-1. Before determination of the SOD activity, samples $(1 \mathrm{ml})$ maintained at $5{ }^{\circ} \mathrm{C}$ were distributed into Eppendorf tubes and sonicated in an ultrasound bath (Fisher Bioblock Scientific, Illkirch, Belgium) at $50 \mathrm{~W}$ for 3 cycles of 2 min intercalated with $30 \mathrm{~s}$ of ice bath. The resulting suspension of bacteria cell lysate was then centrifuged at $3000 \times g$ for 5 min. The supernatants were used for the SOD activity assay. SOD activity in the fruit juices was obtained from a standard curve calculated as equivalents SOD units/mg protein.

\subsection{Evaluation of folates production}

The determination of folate production by the lactobacilli strains was performed in triplicate in samples of 24 and $48 \mathrm{~h}$ of fermentation, for the fruit juice with the best bacteria growth and viability. In order to evaluate the influence of the addition of a precursor on the production of folates, $p$-aminobenzoic acid (PABA) was added at $10 \mu \mathrm{M}$ into fruit juice before fermentation. Then the juice containing PABA was fermented only by the lactobacilli strains which produced folates in the preliminary evaluation. Fermented ( 8,24 and $48 \mathrm{~h}$ of fermentation) and control juices were weighted $(4 \mathrm{~g}$ ), centrifuged at $3000 \times \mathrm{g}$ for $5 \mathrm{~min}$, and the supernatant was taken for folate extraction, deconjugation, derivatization, purification and quantification as described by Delchier, Reich, and Renard (2012), adapted from Ndaw, Bergaentzlé, Aoudé-Werner, Lahély, and Hasselmann (2001), with a deconjugation step using pancreatic chicken homogenate (Pel-Freez Biologicals, Rodgers, AR, USA) at $5 \mathrm{~g} / \mathrm{l}$.

Quantification of folate was carried out on an HPLC (LC 20AD, Shimadzu Inc., Kyoto, Japan) equipped with fluorimetric detector recording at $295 \mathrm{~nm}$ and $356 \mathrm{~nm}$ of excitation and emission wavelengths, respectively. A reversed phase column LiChrospher 100RP18 ( $250 \times 4.6 \mathrm{~mm} ; 5 \mathrm{~mm}$; Alltech, Epernon, France) and a guard column LiChrospher RP18 All Guard ( $7.5 \times 4.6 \mathrm{~mm}$; Alltech) were used for all analysis.

The volume of injection was $100 \mu \mathrm{l}$ and the flow rate of $0.8 \mathrm{ml} / \mathrm{min}$ was applied to the mobile phase consisting of a gradient of solvent $A$ : water and formic acid ( $10 \mathrm{ml} / \mathrm{l})$ and solvent B: acetonitrile. Minor modification was made in the gradient of solvent, which started with $5 \%$ solvent $B$, increased linearly to $100 \%$ of solvent B in $20 \mathrm{~min}$, then the gradient was held to $100 \%$ of solvent B for 10 min followed by linear decrease to $5 \%$ of solvent B in 5 min and an additional elution step for 5 min in order to re-equilibrate the column. Quantification of folates was done against calibration curves constructed with standards (Schircks laboratories, Jona, Switzerland): 5-methyltetrahydrofolic acid monoglutamate and 5-methyltetrahydrofolic acid diglutamate. Results are expressed in equivalent of 5-methyltetrahydrofolic acid monoglutamate in $\mu \mathrm{g} / 100 \mathrm{ml}$ of juice.

\subsection{Hedonic analysis}

The fermented juices with the best bacteria growth and viability, namely apple juices fermented by $L$. acidophilus L10, L. casei L26, L. plantarum $299 \mathrm{v}$ or L. rhamnosus 53103, were selected for the hedonic analysis. The 4 samples were tested by 29 untrained panelists formed by members of the research institute, who are used to analyze hedonic characteristics of food products. The samples were identified with random three-digit codes, distributed in portions of $30 \mathrm{ml}$ into white cups and presented in randomized order. The panelists received the instruction to cleanse their palates with crackers and potable water between tasting samples, which were served at $5{ }^{\circ} \mathrm{C} \pm 2{ }^{\circ} \mathrm{C}$. In order to stave off the shortcoming tendency to avoid the use of the extreme of the categories (Jaeger \& Cardello, 2009), the panelist was asked to mark her (his) evaluation about overall acceptability, odor, color and appearance on a $9 \mathrm{~cm}$ unstructured scale labeled with dislike extremely in the left and like extremely in the right end. The evaluations were measured with a rule and then converted into hedonic scale (between 0 and $1 \mathrm{~cm}=$ dislike extremely, $1-3=$ dislike moderately, $3-5=$ neither like nor dislike, 5-7 = like moderately, and 7-9 = like extremely), adapted from Peryam, Polemis, Kamen, Eindhoven, and Pilgrim (1960) and Caminiti et al. (2012). Participants were further asked to express their free comments on the juice. No information about the potential benefits of the fermented juices to health was given to the participants.

The microbiological safety at food degree of the samples was guaranteed according to European Legislation, through inspection for yeasts $(<10 / \mathrm{ml}$, method NF V08-059) and molds ( $<10 / \mathrm{ml}$, method NF V08059), total coliforms ( $<10 / \mathrm{ml}$, method Petrifilm coliforms $3 \mathrm{M} 囚-01 / 2-$ 09/89 A), Escherichia coli $\beta$ glucuronidase positive $(<10 / \mathrm{ml}$, method Petrifilm E. coli $\left.3 \mathrm{M}{ }^{\circledR}-01 / 8-06 / 01\right)$, Staphylococcus aureus $(<10 / \mathrm{ml}$, method NF V08-057), Pseudomonas sp. (<10/ml, method NF EN ISO 13720), Salmonella sp. (absence/25 g, method IBISA-AES 10/11-07/11), Listeria monocytogenes ( $<100 /$ g, method NF EN ISO 11290-2) and Bacillus cereus $(<100 / \mathrm{ml}$, method NF EN ISO 7932) by an independent certified laboratory (Laboratoire Départemental d'Analyses, Vaucluse, Avignon, France). Hedonic analysis took place 5 days after the fermentation, when the certificate of microbiological safety was delivered. Until then, samples were maintained in refrigerated storage at $5^{\circ} \mathrm{C}$.

\subsection{Statistical analysis}

Data were analyzed by means of ANOVA using XLSTAT® (Addinsoft SARL) data analysis toolbox. Mean differences amongst treatments were assessed by the post-hoc Tukey test considering $\mathrm{P}<0.05$ as significant level. General Linear Model was applied to evaluate the effect of treatment (fermentation or supplementation) and lactobacilli counts during the cold storage period. Statistically significant differences were indicated by labeling the mean values with different letters.

\section{Results and discussion}

3.1. Lactobacillus counts and $\mathrm{pH}$ during fermentation of apple, grape and orange juices

Taken as a whole, there was a significant effect of juice type on lactobacilli growth by $48 \mathrm{~h}$ of fermentation, being their average counts higher in apple juice (8.7-10.3 log CFU/ml) than in grape (8.0-9.8 log $\mathrm{CFU} / \mathrm{ml}$ ) and orange (7.9-8.4 log CFU/ml) juices $(\mathrm{P}<0.05)$, Fig. 1. Furthermore, commercial lactobacilli strains adapted faster to apple juice - in $8 \mathrm{~h}$ of fermentation the bacteria counts increased about $2 \log \mathrm{CFU} / \mathrm{ml}$ - and reached higher counts than the lactobacilli of the same species but isolated from artisanal products (Fig. 1). Noteworthy, L. casei L26 was the strain with the highest counts at $48 \mathrm{~h}$ of fermentation of grape juice. In all fruit juices, L. rhamnosus strains LGG and 607 reached maximum counts at $48 \mathrm{~h}$ of fermentation (Fig. 1).

The initial $\mathrm{pHs}$ ( $\mathrm{pH}$ at t0) of apple, grape and orange juices were 3.7 $( \pm 0.1), 3.4( \pm 0.1)$ and $3.6( \pm 0.1)$, respectively. The average $\mathrm{pH}$ increased by 0.1 units in the first $4 \mathrm{~h}$ of fermentation of apple and grape juices (Fig. 2). As malic acid is the main organic acid in apple and grape juices - but not in orange juice - (Del Campo, Berregi, Caracena, \& Santos, 2006), the period of de-acidification observed at the early stages of fermentation can be mostly ascribed to the conversion of malic acid (a dicarboxylic acid), into lactic acid (a weaker monocarboxylic acid) and carbon dioxide (Liu, 2002; Toit, Engelbrecht, Lerm, \& Krieger-Weber, 2011) by most of the Lactobacillus strains tested herein.

The averages of $\mathrm{pH}$ at $48 \mathrm{~h}$ of fermentation were strain-dependent and ranged between 3.4-3.6, 3.3-3.5 and 3.2-3.4 in apple, grape and orange juices, respectively (Fig. 2).

As expected, lactobacilli counts were inversely and strongly correlated to $\mathrm{pH}(\mathrm{r}=-0.729, \mathrm{P}<0.01)$ in all fruit juices. As a matter of fact, a low $\mathrm{pH}$ was indicated by many authors as one of the main growthlimiting factors for lactic acid bacteria (Serrazanetti, Guerzoni, Corsetti, 
Version définitive du manuscrit publiée dans / Final version of the manuscript published in :

Food Research International (2015), Vol. 78, p. 352-360, DOI: 10.1016/j.foodres.2015.09.014

Journal homepage : www.elsevier.com/locate/foodres

(A)
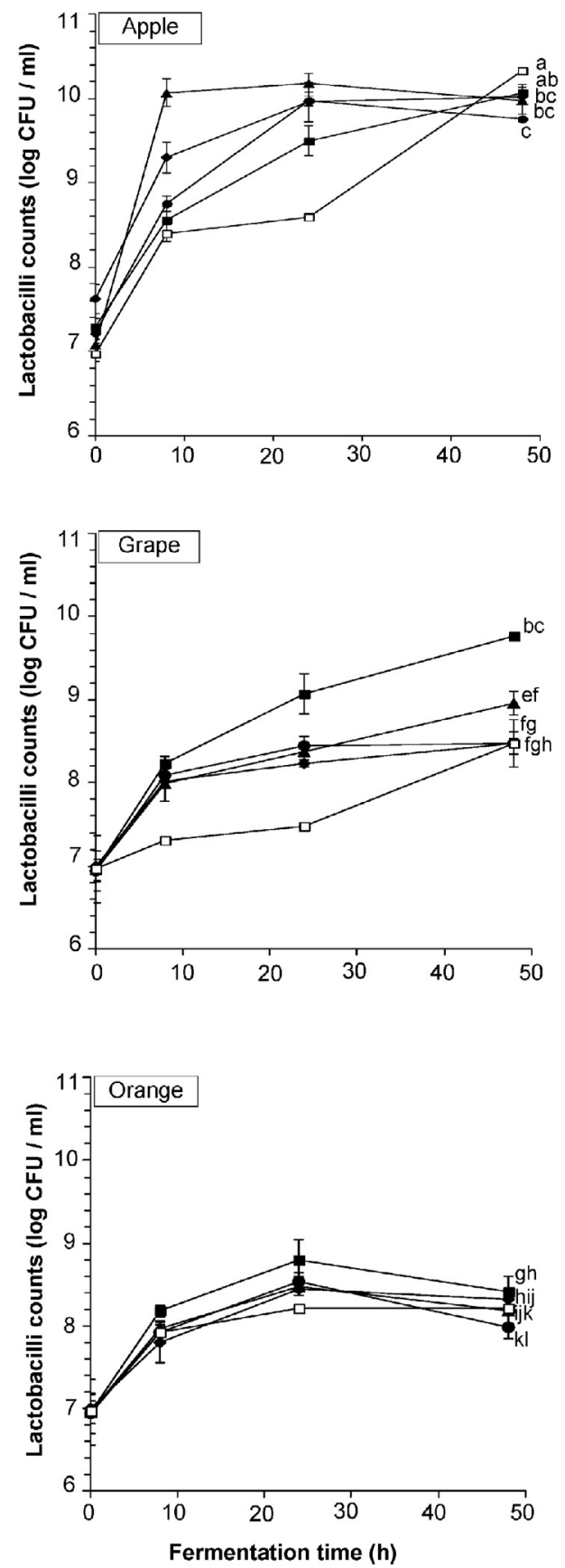

(B)
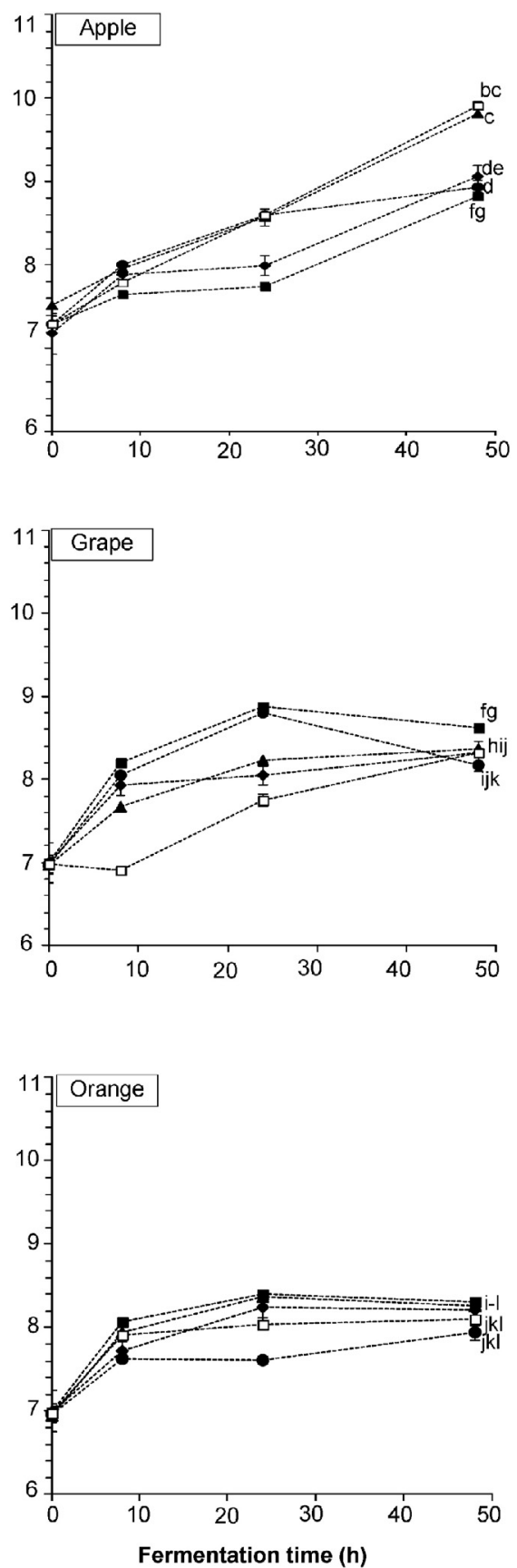

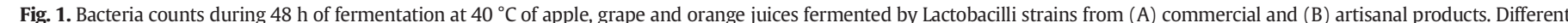

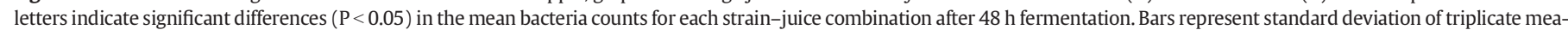

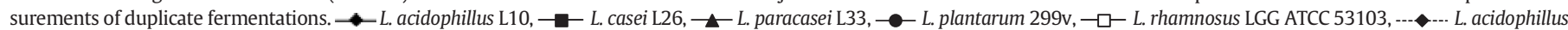

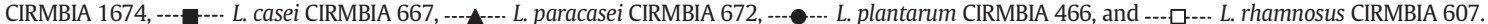

\& Vogel, 2009; Yanez, Marques, Girio, \& Roseiro, 2008). However, as also reported by Sheehan, Ross, and Fitzgerald (2007), the variations of bacteria growth in different fruit juices cannot be ascribed only to the limited variations in $\mathrm{pH}$, but also to the juices chemical composition, as a balance between nutrient and inhibitor compounds for lactobacilli and to the capacity of the strains to adapt to these stressful matrices.

In spite of the former low $\mathrm{pH}$ in fruit juices and the highly probable presence of inhibitor compounds, Lactobacillus strains were able to grow and ferment the fruit juices tested. Rakin et al. (2007) subjected beetroot and carrot juices enriched with brewer's yeast autolysate to fermentation with $L$. acidophilus NCDO1748, obtaining a bacteria growth of about $1-2 \log \mathrm{CFU} / \mathrm{ml}$ by the end of the process, which is similar to the results obtained in the present study for fruit juices without additives.

\subsection{Lactobacillus counts and $\mathrm{pH}$ after cold storage of fermented and of supplemented juices}

Based on the evidence that apple juice was the best substrate for all the lactobacilli strains tested, further analyses were done only for this fruit juice. 
Version définitive du manuscrit publiée dans / Final version of the manuscript published in :

Food Research International (2015), Vol. 78, p. 352-360, DOI: 10.1016/j.foodres.2015.09.014

Journal homepage : www.elsevier.com/locate/foodres

(A)
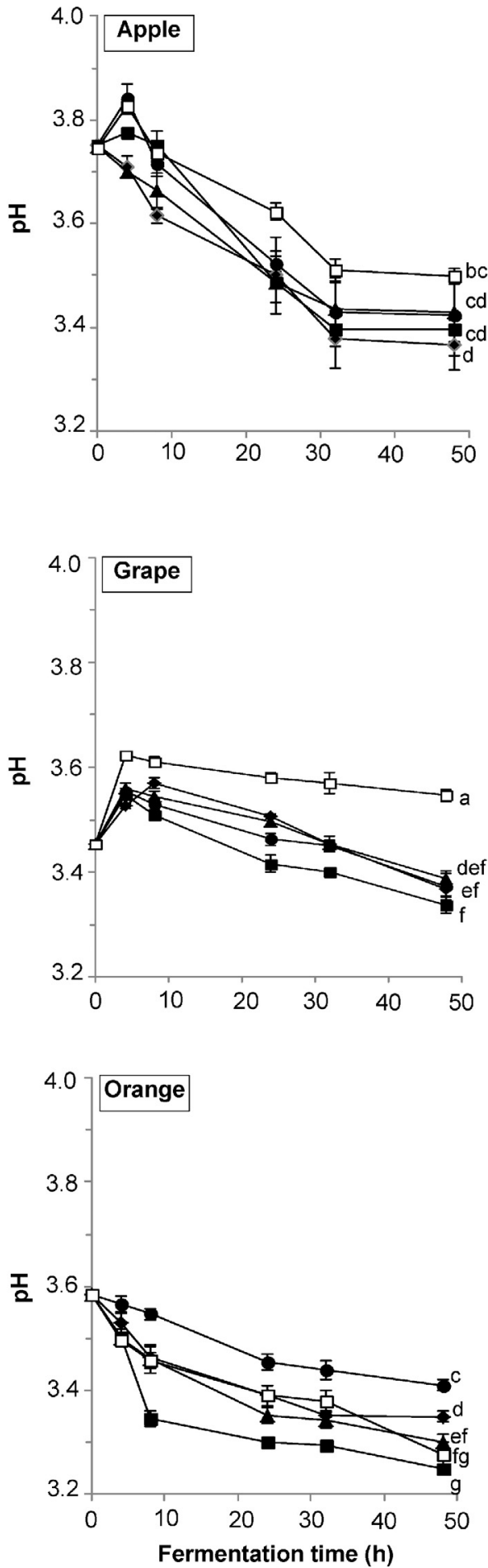

(B)
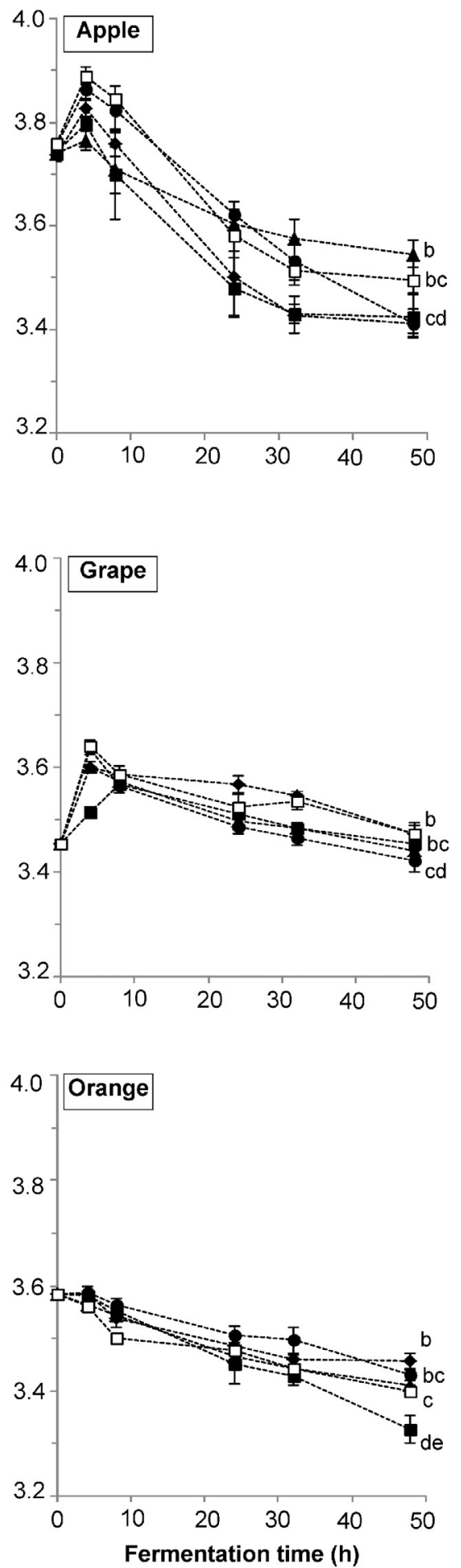

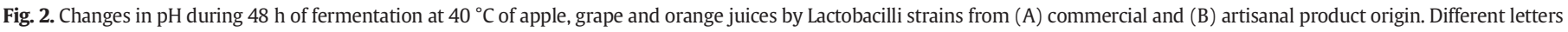

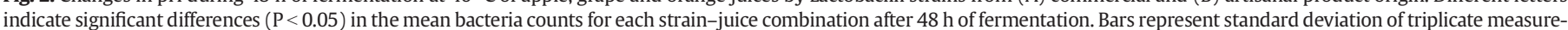

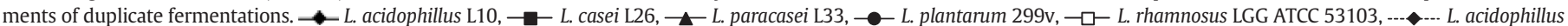

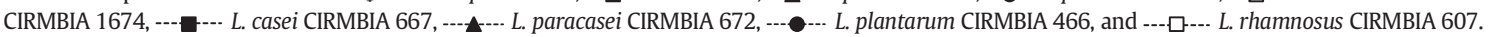

Table 1 presents the decrease of lactobacilli viability calculated as the difference between the bacteria counts on days 1 and 28 , and the $\mathrm{pH}$ of the apple juices on day 28.

Considering the whole period of cold storage, apple juices fermented by L. acidophilus L10 strains and 1674, L. casei strains L26 and 667, L. paracasei 672 , L. plantarum $299 \mathrm{v}$ and L. rhamnosus LGG, showed higher counts of lactobacilli than in juices supplemented with the same strains
$(\mathrm{P}<0.01)$. Moreover, in average, lactobacilli from commercial products had higher cell viability during 28 days than those isolated from artisanal products. The decrease in lactobacilli counts ranged from 0.6 to $4.0 \mathrm{log}$ $\mathrm{CFU} / \mathrm{ml}$, and from 3.3 to $4.8 \mathrm{log} \mathrm{CFU} / \mathrm{ml}$ in fermented and supplemented juices, respectively, being the lowest in apple juice fermented by L. rhamnosus LGG $(\mathrm{P}<0.01)$, and always below the decrease of $7 \mathrm{log}$ $\mathrm{CFU} / \mathrm{ml}$ during cold storage observed by Ding and Shah (2008) in 
Version définitive du manuscrit publiée dans / Final version of the manuscript published in :

Food Research International (2015), Vol. 78, p. 352-360, DOI: 10.1016/j.foodres.2015.09.014

Journal homepage : www.elsevier.com/locatelfoodres

Table 1

Decrease of Lactobacilli counts and $\mathrm{pH}$ on day 28 of cold storage of supplemented and fermented apple juices.

\begin{tabular}{llll}
\hline Microorganisms & Apple juice & $\begin{array}{l}\Delta \text { Lactobacilli counts } \\
(\log \text { CFU/mL) })^{*}\end{array}$ & pH on day $28^{* *}$ \\
\hline Control juice & Not inoculated & & $3.75 \pm 0.03 \mathrm{a}$ \\
L. acidophilus L10 & Supplemented & $3.59 \pm 0.03 \mathrm{bc}$ & $3.70 \pm 0.05 \mathrm{abc}$ \\
L. casei L26 & Supplemented & $3.27 \pm 0.01 \mathrm{cde}$ & $3.68 \pm 0.02 \mathrm{bc}$ \\
L. paracasei L33 & Supplemented & $3.32 \pm 0.01 \mathrm{~cd}$ & $3.67 \pm 0.03 \mathrm{bc}$ \\
L. plantarum 299v & Supplemented & $3.35 \pm 0.01 \mathrm{~cd}$ & $3.70 \pm 0.02 \mathrm{abc}$ \\
L. rhamnosus LGG & Supplemented & $3.39 \pm 0.01 \mathrm{~cd}$ & $3.65 \pm 0.03 \mathrm{ab}$ \\
L. acidophilus 1674 & Supplemented & $4.61 \pm 0.02 \mathrm{a}$ & $3.72 \pm 0.02 \mathrm{abc}$ \\
L. casei 667 & Supplemented & $4.77 \pm 0.02 \mathrm{a}$ & $3.72 \pm 0.02 \mathrm{abc}$ \\
L. paracasei 672 & Supplemented & $4.69 \pm 0.01 \mathrm{a}$ & $3.70 \pm 0.03 \mathrm{abc}$ \\
L. plantarum 466 & Supplemented & $3.36 \pm 0.01 \mathrm{~cd}$ & $3.70 \pm 0.02 \mathrm{abc}$ \\
L. rhamnosus 607 & Supplemented & $3.92 \pm 0.26 \mathrm{~b}$ & $3.69 \pm 0.03 \mathrm{bc}$ \\
L. acidophilus L10 & Fermented & $2.01 \pm 0.05 \mathrm{gh}$ & $3.30 \pm 0.02 \mathrm{def}$ \\
L. casei L26 & Fermented & $2.20 \pm 0.01 \mathrm{~g}$ & $3.35 \pm 0.04 \mathrm{def}$ \\
L. paracasei L33 & Fermented & $2.94 \pm 0.10 \mathrm{de}$ & $3.25 \pm 0.04 \mathrm{~g}$ \\
L. plantarum 299v & Fermented & $1.66 \pm 0.09 \mathrm{~h}$ & $3.35 \pm 0.03 \mathrm{def}$ \\
L. rhamnosus LGG & Fermented & $0.64 \pm 0.01 \mathrm{i}$ & $3.41 \pm 0.04 \mathrm{de}$ \\
L. acidophilus 1674 & Fermented & $2.36 \pm 0.02 \mathrm{fg}$ & $3.36 \pm 0.05 \mathrm{def}$ \\
L. casei 667 & Fermented & $2.77 \pm 0.01 \mathrm{ef}$ & $3.38 \pm 0.04 \mathrm{def}$ \\
L. paracasei 672 & Fermented & $3.76 \pm 0.03 \mathrm{bc}$ & $3.49 \pm 0.03 \mathrm{~d}$ \\
L. plantarum 466 & Fermented & $3.55 \pm 0.05 \mathrm{bc}$ & $3.37 \pm 0.03 \mathrm{def}$ \\
L. rhamnosus 607 & Fermented & $4.01 \pm 0.06 \mathrm{~b}$ & $3.44 \pm 0.04 \mathrm{de}$ \\
\hline
\end{tabular}

a $\Delta$ Lactobacillus counts $=$ Lactobacillus counts on day $1-$ Lactobacillus counts on day $28(\log \mathrm{CFU} / \mathrm{mL})$.

* Values given are means $(n=6) \pm$ sum of the variances. Means with different letters in the same column are significantly different $(\mathrm{P}<0.05)$.

** Values given are means $(n=6) \pm$ standard deviation. Means with different letters in the same column are significantly different $(\mathrm{P}<0.05)$.

buffered apple juice supplemented with free L. acidophilus, L. paracasei, L. plantarum or L. rhamnosus. The viability of Lactobacillus during 4 weeks of cold storage in the apple juice tested herein was higher than in pomegranate juice fermented by L. plantarum, L. acidophilus and L. paracasei (Mousavi, Mousavi, Razavi, Emam-Djomeh, \& Kiani, 2011) and comparable to the probiotic bacteria viability in stirred fruit yoghurts (Kailasapathy, Harmstorf, \& Phillips, 2008) and even in petit Suisse cheese (Esmerino et al., 2013). Apple juice thus appeared to be a suitable matrix to insure the viability of lactobacilli during cold storage. A possible explanation for the better lactobacilli viability in supplemented apple juice in our study could be the gradual adaptation of the cultures to the stressful conditions of the fruit juices, as described in Section 2.3.

Noteworthy, during 4 weeks of cold storage, lactobacilli counts remained above 5-6 $\log \mathrm{CFU} / \mathrm{ml}$ which represents, considering a dose of $100 \mathrm{ml}$ of fermented apple juice, the generally recommended daily probiotic intake of $8 \log$ CFU to be perceived beneficial effects to the host (Mihatsch et al., 2012; Taverniti, Scabiosi, Arioli, Mora, \& Guglielmetti, 2014).

Various methods have been proposed to improve cell viability during storage: microencapsulation of probiotic bacteria (Burgain, Gaiani, Linder, \& Scher, 2011; Ding \& Shah, 2008; Nualkaekul, Lenton, Cook, Khutoryanskiy, \& Charalampopoulos, 2012; Rokka \& Rantamäki, 2010), adhesion to prebiotic fibers (Saarela, Virkajärvi, Nohynek, Vaari, \& Mättö, 2006) or addition of protective compounds and pH control of the food matrix (Pereira, Maciel, \& Rodrigues, 2011; Rakin et al., 2007). Herein, the best survival of lactobacilli during cold storage of fermented apple juice might be due to the selection, during fermentation, of bacteria individuals that mostly adapted to the apple juice environment, thus surviving longer than the same Lactobacillus strains simply supplemented into apple juice. This observation encourages the fermentation of apple juice as an alternative to maintain the recommended beneficial bacteria counts during the shelf-life.

During cold storage, the $\mathrm{pH}$ of the lactobacilli-supplemented apple juices did not decrease significantly in relation to the nonsupplemented control $(\mathrm{P}>0.05)$, Table 1 . Likewise, the $\mathrm{pH}$ of the fermented apple juices showed no difference $(P>0.05)$ between the days 1 and 28 of cold storage, which could be ascribed to the reduction on cell viability with consequent reduction of organic acid production, Table 1.

The decrease of pHs ( 0.4 unit maximum) during fermentation and cold storage, could be regarded as the result of different acidifying capacity of the strains in the juices tested, and also to the buffering capacity of these substrates (Lussi, Kohler, Zero, Schaffner, \& Megert, 2000).

\subsection{Superoxide dismutase activity}

SOD activity in control apple juice (non-inoculated) at t0 was of 9.9 units/mg protein, close to the 10 units/mg protein reported by Masia (1998) in Golden apple extracts, considering the dry weight. Nevertheless, this initial SOD activity was significantly reduced to 5.8 units/mg protein at $\mathrm{t} 48(\mathrm{P}<0.01)$, Fig. $3 \mathrm{~A}$ and $\mathrm{B}$.

SOD activity decreased sharply yet in the first $4 \mathrm{~h}$ of fermentation of apple juice by most of the lactobacilli strains - particularly those from commercial origin, Fig. $3 \mathrm{~A}$ and $\mathrm{B}$. The reduction of SOD activity in control juice and in fermented juice at the early stages of fermentation can be due to the sensibility of the enzyme to the temperature of fermentation $\left(40{ }^{\circ} \mathrm{C}\right)$, its inactivation by compounds present in the fruit juice and/or produced by the lactobacilli such as exopolysaccharides as a reaction to acidic stressful environment (Welman \& Maddox, 2003), or by a combination of factors. Further studies are needed to elucidate what these SOD-inhibitors are.

On the other hand, the SOD activity increased significantly after $4 \mathrm{~h}$ of fermentation and its maximum ranged from 15.3 to 15.9 and from 9.2 to 14.0 units/mg of protein in apple juices fermented by strains from commercial and from artisanal origin, respectively (Fig. 3A and B). Furthermore, in general, the maximum SOD activity was reached in $24 \mathrm{~h}$ of fermentation by commercial strains of Lactobacillus and in $48 \mathrm{~h}$ in apple juices fermented by strains from artisanal product origin. Taken as a whole, the SOD activity in all fermented apple juices was found to be strongly correlated to bacteria counts $(r=0.624, \mathrm{P}<0.001)$, pointing out that the ability of lactobacilli to produce anti-oxidative substances such as SOD is one of the factors of furthest importance to cell viability, as they minimize the deleterious effects of ROS accumulated during fermentation in aerobic conditions (Lin \& Yen, 1999). To the best of our knowledge, it is the first time that the profile of production of SOD by lactobacilli during fermentation of a fruit juice is reported.

\subsection{Production of folates}

The presence of folates - expressed as folic acid equivalent - was observed only in apple juice fermented by strains of $L$. plantarum and L. rhamnosus. As these Lactobacillus species are also consumers of folates, the averages of folic acid equivalent presented in Fig. $4 \mathrm{~A}$ and $\mathrm{B}$ should be taken as the result of folates production and consumption.

On the one hand, folate production began at $24 \mathrm{~h}$ of fermentation but the highest concentrations were reached at $48 \mathrm{~h}$ in juices fermented by the commercial strains $L$. plantarum $299 \mathrm{v}(1.03 \mu \mathrm{g} / 100 \mathrm{ml})$ and L. rhamnosus LGG $(1.26 \mu \mathrm{g} / 100 \mathrm{ml})$. On the other hand, when PABA was added at $10 \mu \mathrm{M}$, the production of folates was higher at $24 \mathrm{~h}$ than at $48 \mathrm{~h}$ of fermentation $(\mathrm{P}<0.05)$ and the concentrations were the highest in apple juices fermented by the two strains of L. plantarum, Fig. $4 \mathrm{~A}$ and B. Considering the strains of $L$. plantarum 299v and CIRMBIA 466 and of L. rhamnosus LGG and CIRMBIA 607, the folates level was positively correlated with $L$. plantarum and $L$. rhamnosus counts $(r=0.627, \mathrm{P}<0.001)$ either supplemented or not with PABA. The supplementation of apple juice with PABA may have anticipated by $24 \mathrm{~h}$ the peak of maximum lactobacilli counts (data not shown), and thus the formation of folates. However production of folates was not increased in proportion to the amount of precursor added $(10 \mu \mathrm{M})$, as maximum folate concentration in the medium was below $1.8 \mu \mathrm{g} / 100 \mathrm{ml}(0.4 \mu \mathrm{M})$. The influence of bacteria counts and fermentation time on folate level was also reported by Lin and Young (2000), who observed a significant reduction in folate 
Version définitive du manuscrit publiée dans / Final version of the manuscript published in :

Food Research International (2015), Vol. 78, p. 352-360, DOI: 10.1016/j.foodres.2015.09.014

Journal homepage : www.elsevier.com/locate/foodres

(A)

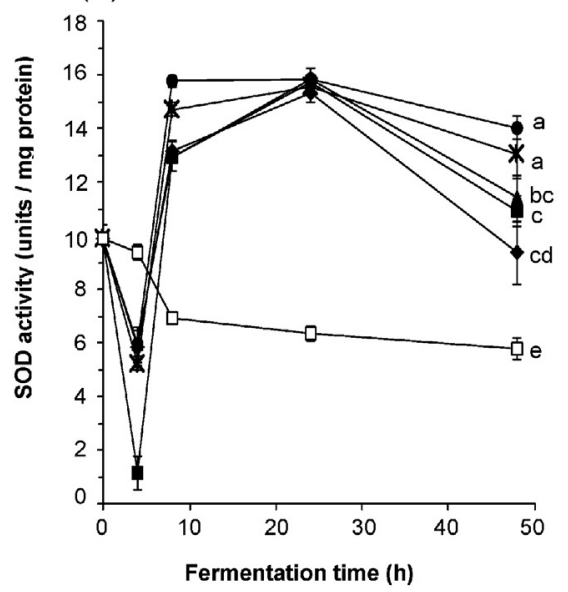

(B)

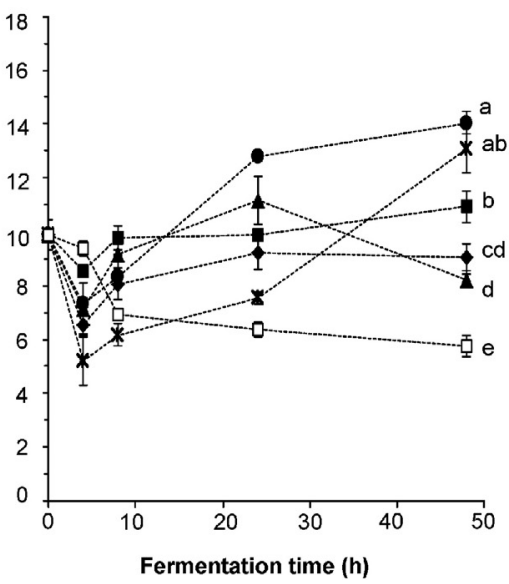

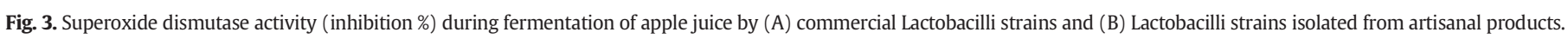

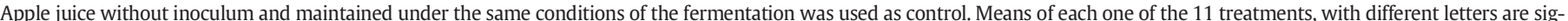

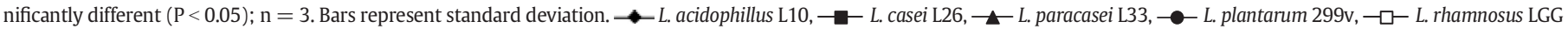

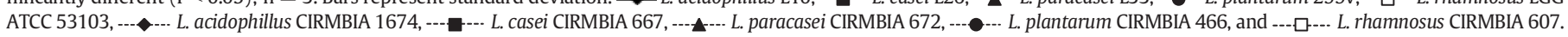

concentration after this reached a maximum during fermentation of complex media by Lactobacillus strains.

The amounts of folates present in apple juices fermented by L. plantarum and L. rhamnosus strains are not high enough to consider them as source of folates, which recommended dietary allowances (RDA) range between $300 \mu \mathrm{g}-1000 \mu \mathrm{g}$, depending on population category (Morales, Fernández-Ruiz, Sánchez-Mata, Cámara, \& Tardío, 2015). Notwithstanding, these findings encourage the pursuit of prospective studies for strain selection in order to increase folates production by $L$. plantarum and L. rhamnosus in vegetable food matrix.

\subsection{Hedonic analysis}

Participants $(\mathrm{n}=29)$ in the panel were mostly women $(62 \%), 26$ 35 years old (28\%) or $36-50$ years old (34\%), pay attention to their daily diet (55\%), drink fruit juice 1-5 times/week (55\%) and are familiar with fermented foods (100\%).

Although the average scores for overall acceptability, taste and appearance were not significantly different (5.1-6.2 = like moderately), a tendency of higher scores for apple juices fermented by L. acidophilus L10 was observed, as summarized in Fig. 5. However, the odor of the apple juice fermented by L. rhamnosus 53103 was significantly $(\mathrm{P}<0.05)$ less appreciated $(3-5=$ neither like nor dislike) than the juice fermented by L. acidophilus L10 (6-7 = like moderately). Considering the average score in the hedonic scale for overall acceptability, apple juice fermented by L. plantarum $299 \mathrm{v}$ received the worst acceptance (17\% dislike extremely) and those fermented by L. acidophilus L10 and by $L$. casei $\mathrm{L} 26$ were the best accepted, with 28 and $24 \%$, respectively, of scores like very much-like extremely (Fig. 5).

Most of the participants who left further observations, considered the taste "characteristic of apple juice" (19) and "sweet" (17). Only 3 participants remarked a "baked apple" taste in the samples, which can be ascribed to the exposition of the juices to $40{ }^{\circ} \mathrm{C}$ during $48 \mathrm{~h}$ of fermentation. A "fermented dairy" taste and odor were perceived by 10 participants, as the result of fermentation by lactic acid bacteria. The color was described as "dark yellow" (2), "bright yellow" (3), "correct for an apple juice" (3) and "very pale yellow" (9) in apple juices fermented by L. acidophilus L10, L. casei L26, L. plantarum 299v and L. rhamnosus LGG ATCC 53103, respectively.

The taste and odor of fermented dairy food can be probably ascribed to the presence of compounds such as acetoin, diacetyl and 2,3butanediol produced by LAB from the catabolism of pyruvate under
(A)

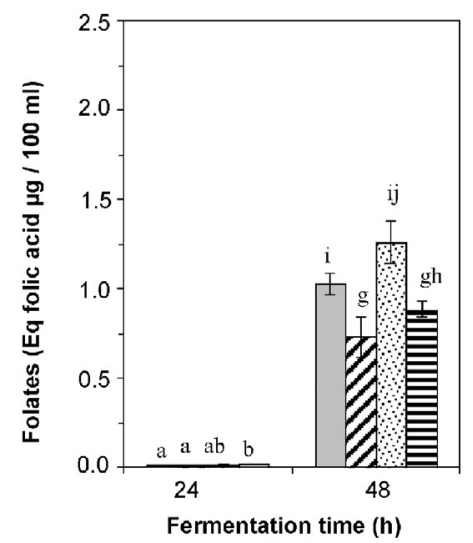

(B)

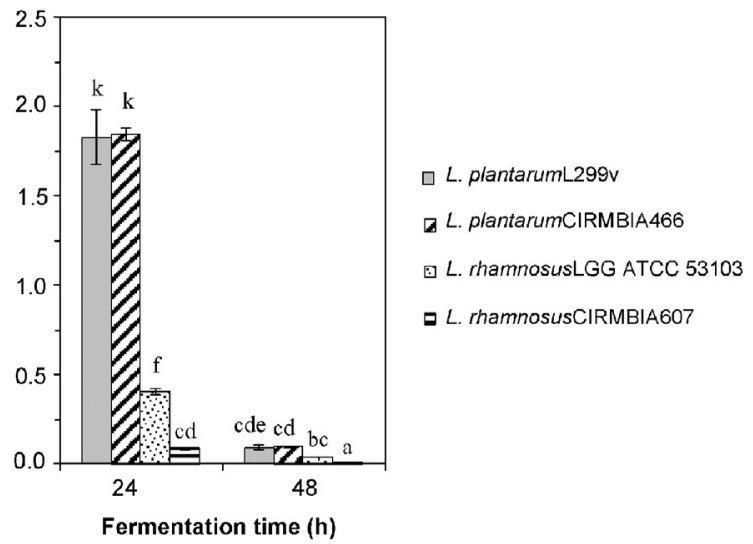

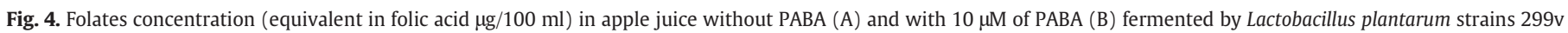
and CIRMBIA 466 and L. rhamnosus strains LGG ATCC 53103 and CIRMBIA 607. Means with different letters are significantly different $(\mathrm{P}<0.05)$, $\mathrm{n}=3$. 
Version définitive du manuscrit publiée dans / Final version of the manuscript published in :

Food Research International (2015), Vol. 78, p. 352-360, DOI: 10.1016/j.foodres.2015.09.014

Journal homepage : www.elsevier.com/locatelfoodres
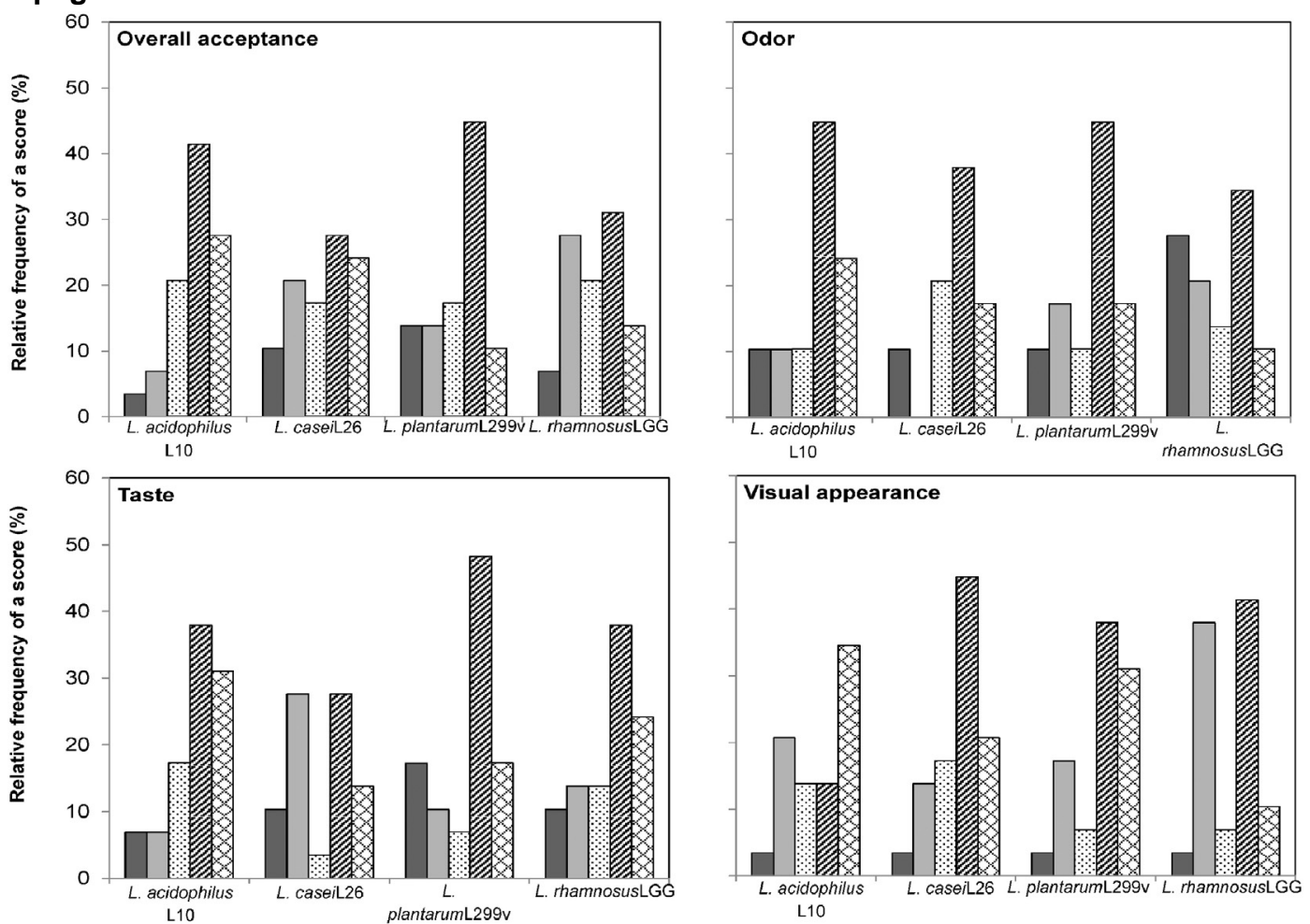

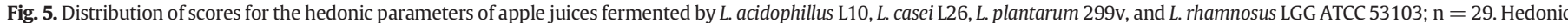
scale: $0-1=\square$ Dislike extremely; $1-3=\square$ Dislike moderately; 3-5 = . Neither like nor dislike; 5-7 = $\mathbb{Z}$ Like moderately; 7-9= $\otimes$ Like extremely.

aerobic conditions (Liu, 2003). As the lactobacilli consumed sugars present in the apple juice during fermentation (data not shown), the sweetness remarked by some of the participants can be due to the apple variety chosen for this study, i.e. var. Golden, which has a high sugar/ acid ratio (Eisele \& Drake, 2005). Furthermore, the conversion of malic into the weaker lactic acid (Toit et al., 2011) by Lactobacillus may have reinforced the sweet in-mouth feeling.

The overall acceptability was found to be strongly correlated with the taste $(\mathrm{r}=0.845, \mathrm{P}<0.0001)$ and with the odor $(\mathrm{r}=0.713, \mathrm{P}<0.0001)$, but not with the visual appearance $(P>0.05)$ of the fermented juices.

The flavors of orange juices supplemented with L. rhamnosus LGG, L. casei Imunitass ${ }^{\circledR}$, or $L$. paracasei NFBC 43338 are described as 'dairy,' 'savory,' and 'medicinal' (Luckow, Sheehan, Delahunty, \& Fitzgerald, 2005). However, after 7 days of consumption of probiotic supplemented juices, a 'mere-exposure' effect - which is the increase in liking scores upon frequent consumer exposure to a food product - is observed (Luckow et al., 2005). Thus, to improve the acceptation of apple juices fermented by Lactobacilli, one can suggest the familiarization of the consumers to this new product.

\section{Conclusions}

In general, lactobacilli counts were higher in apple juice than in grape and orange juices by $48 \mathrm{~h}$ of fermentation. Moreover, the commercial lactobacilli strains L. acidophilus Lafti L10, L. casei Lafti L26, L. plantarum 299v and L. rhamnosus LGG ATCC 53103 showed higher growth and viability in fermented apple juice than the ones isolated from artisanal products: L. acidophilus CIRMBIA 1674, CNRZ 204, L. casei CIRMBIA 667, CNRZ 313, L. plantarum CIRMBIA 466, CNRZ 211 and L. rhamnosus CIRMBIA 607, CNRZ 212, which highlights the importance of prospective studies for selection of the strain the most adaptable to a given food substrate.

The fermentation process, rather than the simple supplementation, insured greater viability of most of the lactobacilli strains tested during the four weeks of cold storage. Furthermore, other benefits of fermentation were observed such as an increase of SOD activity and folates concentration in apple juice. To the best of our knowledge, it is the first time that the production of folates in apple juices fermented by L. plantarum and by L. rhamnosus, is reported.

In spite of the fermented dairy odor remarked by some members of the panel, the overall acceptability, odor, taste and visual appearance of apple juices fermented by L. acidophilus Lafti L10, L. casei Lafti L26, L. plantarum 299v and L. rhamnosus LGG ATCC 53103 were scored as "like moderately", encouraging further studies of product development.

These findings meet the needs of the expanding probiotic market, eager for novelties, suggesting apple juice as a suitable alternative to the dairy-based matrices for probiotic food formulation and fermentation as a process to improve the Lactobacillus viability and potentially, the functional aspects of the food product.

\section{Acknowledgments}

This work was supported with a post-doctoral grant $\left(n^{\circ} 163\right)$ from the program AgreenSkills-INRA, France. The authors are grateful to Globalfood (São Paulo, Brazil) and DSM Food Specialties (Heerlen, Netherlands) for the donation of L. acidophilus Lafti L10 and L. casei Lafti L26 cultures. Thanks are due to Caroline Garcia, Marie-Hélène Guinebretière and Stéphanie Chamot for their skillful technical assistance.

\section{References}

Agyei, D., \& Danquah, M. K. (2012). Rethinking food-derived bioactive peptides for antimicrobial and immunomodulatory activities. Trends in Food Science \& Technology, 23(2), 62-69.

Ankolekar, C., Pinto, M., Greene, D., \& Shetty, K. (2012). In vitro bioassay based screening of antihyperglycemia and antihypertensive activities of Lactobacillus acidophilus fermented pear juice. Innovative Food Science \& Emerging Technologies, 13, 221-230.

Burgain, J., Gaiani, C., Linder, M., \& Scher, J. (2011). Encapsulation of probiotic living cells: From laboratory scale to industrial applications. Journal of Food Engineering, 104(4), 467-483.

Caminiti, I. M., Palgan, I., Muñoz, A., Noci, F., Whyte, P., Morgan, D. J., ... Lyng, J. G. (2012) The effect of ultraviolet light on microbial inactivation and quality attributes of apple juice. Food and Bioprocess Technology, 5, 680-686. 


\section{Version définitive du manuscrit publiée dans / Final version of the manuscript published in : \\ Food Research International (2015), Vol. 78, p. 352-360, DOI: 10.1016/j.foodres.2015.09.014 \\ Journal homepage : www.elsevier.com/locate/foodres}

Champagne, C. P., Raymond, Y., \& Gagnon, R. (2008). Viability of Lactobacillus rhamnosus R0011 in an apple-based fruit juice under simulated storage conditions at the consumer level. Journal of Food Science, 73(5), M221-M226.

Del Campo, G., Berregi, I., Caracena, R., \& Santos, J. I. (2006). Quantitative analysis of malic and citric acids in fruit juices using proton nuclear magnetic resonance spectroscopy. Analytica Chimica Acta, 556, 462-468.

Delchier, N., Reich, M., \& Renard, C. M. G. C. (2012). Impact of cooking methods on folates, ascorbic acid and lutein in green beans (Phaseolus vulgaris) and spinach (Spinacea oleracea). LWT - Food Science and Technology, 49, 197-201.

Ding, W. K., \& Shah, N. P. (2008). Survival of free and microencapsulated probiotic bacteria in orange and apple juices. International Food Research Journal, 15(2), 219-232.

Eisele, T. A., \& Drake, S. R. (2005). The partial compositional characteristics of apple juice from 175 apple varieties. Journal of Food Composition and Analysis, 18, 213-221.

Esmerino, E. A., Cruz, A. G., Pereira, E. P. R., Rodrigues, J. B., Faria, J. A. F., \& Bolini, H. M. A. (2013). The influence of sweeteners in probiotic petit Suisse cheese in concentrations equivalent to that of sucrose. Journal of Dairy Science, 96(9), 5512-5521.

Espirito Santo, A. P., Perego, P., Converti, A., \& Oliveira, M. N. (2011). Influence of food matrices on probiotic viability - A review focusing on the fruity bases. Trends in Food Science E' Technology, 22, 377-385.

Espírito-Santo, A. P., Cartolano, N. S., Silva, T. F., Soares, F. A. S. M., Gioielli, L. A., Perego, P., ... Oliveira, M. N. (2012). Fibers from fruit by-products enhance probiotic viability and fatty acid profile and increase CLA content in yoghurts. International Journal of Food Microbiology, 154, 135-144.

FAO/WHO (2006). Probiotics in food - Health and nutritional properties and guidelines for evaluation. Rome: Food and Agriculture Organization of the United Nations and World Health Organization expert consultation report. Retrieved February 1, 2015 from ftp://ftp.fao.org/docrep/fao/009/a0512e/a0512e00.pdf

Foligné, B., Daniel, C., \& Pot, B. (2013). Probiotics from research to market: The possibilities, risks and challenges. Current Opinion in Microbiology, 16, 284-292.

Galdeano, C. M., \& Perdigon, G. (2004). Role of viability of probiotic strains in their persistence in the gut and in mucosal immune stimulation. Journal of Applied Microbiology, 97, 673-681.

Gobbetti, M., Di Cagno, R., \& De Angelis, M. (2010). Functional microorganisms for functional food quality. Critical Reviews in Food Science and Nutrition, 50(8), 716-727.

Granato, D., Branco, G. F., \& Nazzaro, F. (2010). Functional foods and nondairy probiotic food development: trends, concepts and products. Comprehensive Reviews in Food Science and Food Safety, 9, 292-302.

Hou, J. -W., Yu, R. -C., \& Chou, C. -C. (2000). Changes in some components of soymilk during fermentation with bifidobacteria. Food Research International, 33, 393-397.

Hubert, B., Baron, A., Le Queré, J. -M., \& Renard, C. M. G. C. (2007). Influence of prefermentary clarification on the composition of apple musts. Journal of Agricultural and Food Chemistry, 55, 5118-5122

Isolauri, E., Salminen, S., \& Ouwehand, A. C. (2004). Probiotics. Best Practice Er Research Clinical Gastroenterology, 18(2), 299-313.

Jaeger, S. R., \& Cardello, A. V. (2009). Direct and indirect hedonic scaling methods: A comparison of the labeled affective magnitude (LAM) scale and best-worst scaling. Food Quality and Preference, 20, 249-258.

Jägerstad, M., Jastrebova, J., \& Svensson, U. (2004). Folates in fermented vegetables - A pilot study. LWT - Food Science and Technology, 37, 603-611.

Jones, M. L., Tomaro-Duchesneau, C., \& Prakash, S. (2014). The gut microbiome, probiotics, bile acids axis, and human health. Trends in Microbiology, 22(6), 306-308.

Kailasapathy, K., Harmstorf, I., \& Phillips, M. (2008). Survival of Lactobacillus acidophilus and Bifidobacterium animalis ssp. lactis in stirred fruit yogurts. LWT - Food Science and Technology, 41, 1317-1322.

Katan, M. B. (2012). Why the European Food Safety Authority was right to reject health claims for probiotics. Beneficial Microbes, 3(2), 85-89.

LeBlanc, J. G., Milani, C., de Giori, G. S., Sesma, F., van Sinderen, D., \& Ventura, M. (2013). Bacteria as vitamin suppliers to their host: A gut microbiota perspective. Current Opinion in Biotechnology, 24, 160-168.

Lin, M. -Y., \& Yen, C. -L. (1999). Antioxidative ability of lactic acid bacteria. Journal of Agricultural and Food Chemistry, 47, 1460-1466.

Lin, M. Y., \& Young, C. M. (2000). Folate levels in cultures of lactic acid bacteria. International Dairy Journal, 10, 409-413.

Liu, S. -Q. (2002). Malolactic fermentation in wine - Beyond deacidification. Journal of Applied Microbiology, 92, 589-601.

Liu, S. -Q. (2003). Practical implications of lactate and pyruvate metabolism by lactic acid bacteria in food and beverage fermentations. International Journal of Food Microbiology, 83, 115-131.

Luckow, T., Sheehan, V., Delahunty, C., \& Fitzgerald, G. -M. (2005). Determining the odor and flavor characteristics of probiotic, health promoting ingredients and the effects of repeated exposure on consumer acceptance. Journal of Food Science, 70(1), S53-S59.

Lussi, A., Kohler, N., Zero, D., Schaffner, M., \& Megert, B. (2000). A comparison of the erosive potential of different beverages in primary and permanent teeth using an in vitro model. European Journal of Oral Sciences, 108, 110-114.
Martins, E. M. F., Ramos, A. M., Vanzela, E. S. L., Stringheta, P. C., Pinto, C. L. O., \& Martins, J. M. (2013). Products of vegetable origin: A new alternative for the consumption of probiotic bacteria. Food Research International, 51, 764-770.

Masia, A. (1998). Superoxide dismutase and catalase activities in apple fruit during ripening and post-harvest and with special reference to ethylene. Physiologia Plantarum, 104, 668-672.

Mattila-Sandholm, T., Myllärinen, P., Crittenden, R., Mogensen, G., Fondén, R., \& Saarela, M. (2002). Technological challenges for future probiotic foods. International Dairy Journal, 12, 173-182.

Mihatsch, W. A., Braegger, C. P., Decsi, T., Kolacek, S., Lanzinger, H., Mayer, B., ... van Goudoever, J. B. (2012). Critical systematic review of the level of evidence for routine use of probiotics for reduction of mortality and prevention of necrotizing enterocolitis and sepsis in preterm infants. Clinical Nutrition, 31, 6-15.

Morales, P., Fernández-Ruiz, V., Sánchez-Mata, M. C., Cámara, M., \& Tardío, J. (2015). Optimization and application of FL-HPLC for folates analysis in 20 species of Mediterranean wild vegetables. Food Analytical Methods, 8, 302-311.

Mousavi, Z. E., Mousavi, S. M., Razavi, S. H., Emam-Djomeh, Z., \& Kiani, H. (2011). Fermentation of pomegranate juice by probiotic lactic acid bacteria. World Journal of Microbiology and Biotechnology, 27, 123-128.

Ndaw, S., Bergaentzlé, M., Aoudé-Werner, D., Lahély, S., \& Hasselmann, C. (2001). Determination of folates in foods by high-performance liquid chromatography with fluorescence detection after precolumn conversion to 5-methyltetrahydrofolates. Journal of Chromatography A, 928(1), 77-90.

Nualkaekul, S., Lenton, D., Cook, M. T., Khutoryanskiy, V. V., \& Charalampopoulos, D. (2012). Chitosan coated alginate beads for the survival of microencapsulated Lactobacillus plantarum in pomegranate juice. Carbohydrate Polymers, 90, 1281-1287.

Peran, L., Camuesco, D., Comalada, M., Bailon, E., Henriksson, A., Xaus, J., ... Galvez, J. A. (2007). Comparative study of the preventive effects exerted by three probiotics, Bifidobacterium lactis, Lactobacillus casei and Lactobacillus acidophilus, in the TNBS model of rat colitis. Journal of Applied Microbiology, 103, 836-844.

Pereira, A. L. F., Maciel, T. C., \& Rodrigues, S. (2011). Probiotic beverage from cashew apple juice fermented with Lactobacillus casei. Food Research International, 44, 1276-1283.

Peryam, D. R., Polemis, B. W., Kamen, J. M., Eindhoven, G., \& Pilgrim, F. J. (1960). Food preference of men in the US armed forces. Chicago, IL: Departement of the Army Quatermaster Research and Engineering Comand-Quatermaster Food and Container Institute for the Armed Forces.

Rakin, M., Vukasinovic, M., Siler-Marinkovic, S., \& Maksimovic, M. (2007). Contribution of lactic acid fermentation to improved nutritive quality vegetable juices enriched with brewer's yeast autolysate. Food Chemistry, 100, 599-602.

Ranadheera, C. S., Baines, S. K., \& Adams, M. C. (2010). Importance of food in probiotic efficacy. Food Research International, 43, 1-7.

Rokka, S., \& Rantamäki, P. (2010). Protecting probiotic bacteria by microencapsulation: Challenges for industrial applications. European Food Research and Technology, 231, $1-12$.

Saarela, M., Virkajärvi, I., Nohynek, L., Vaari, A., \& Mättö, J. (2006). Fibres as carriers for Lactobacillus rhamnosus during freeze-drying and storage in apple juice and chocolate-coated breakfast cereals. International Journal of Food Microbiology, 112, 171-178.

Serrazanetti, D. I., Guerzoni, M. E., Corsetti, A., \& Vogel, R. (2009). Metabolic impact and potential exploitation of the stress reactions in lactobacilli. Food Microbiology, 26, 700-711.

Sheehan, V. M., Ross, P., \& Fitzgerald, G. F. (2007). Assessing the acid tolerance and the technological robustness of probiotic cultures for fortification in fruit juices. Innovative Food Science \& Emerging Technologies, 8, 279-284.

Siegrist, M., Stampfli, N., \& Kastenholz, H. (2008). Consumers' willingness to buy functional foods. The influence of carrier, benefit and trust. Appetite, 51, 526-529.

Stanton, C., Ross, R. P., Fitzgerald, G. F., \& Van Sinderen, D. (2005). Fermented functional foods based on probiotics and their biogenic metabolites. Current Opinion in Biotechnology, 16, 198-203.

Taverniti, V., Scabiosi, C., Arioli, S., Mora, D., \& Guglielmetti, S. (2014). Short-term daily intake of 6 billion live probiotic cells can be insufficient in healthy adults to modulate the intestinal bifidobacteria and lactobacilli. Journal of Functional Foods, 6, 482-491.

Toit, M., Engelbrecht, L., Lerm, E., \& Krieger-Weber, S. (2011). Lactobacillus: The next generation of malolactic fermentation starter cultures-An overview. Food and Bioprocess Technology, 4, 876-906.

Wang, Y. -C., Yu, R. -C., \& Chou, C. -C. (2006). Antioxidative activities of soymilk fermented with lactic acid bacteria and bifidobacteria. Food Microbiology, 23, 128-135.

Welman, A. D., \& Maddox, I. S. (2003). Exopolysaccharides from lactic acid bacteria: perspectives and challenges. Trends in Biotechnology, 21, 269-274.

Yanez, R., Marques, S., Girio, M. F., \& Roseiro, J. C. (2008). The effect of acid stress on lactate production and growth kinetics in Lactobacillus rhamnosus cultures. Process Biochemistry, 43, 356-361. 